\title{
Legal Status of a Minor in Giving Consent to Treatment from the Perspective of the Malaysian Child Act 2001
}

\section{Tengku Noor Azira Tengku Zainudin (Dr PHD)}

Lecturer in the Faculty of Law, National University of Malaysia

\author{
Anita Abdul Rahim (Dr PHD) \\ Lecturer in the Faculty of Law, National University of Malaysia \\ Mohamad Afiq Taqiudin Roslan
}

Student/Research Assistant, Faculty of Law, National University of Malaysia

Doi:10.5901/ajis.2013.v2n9p278

\section{Abstract}

Patient's autonomy to make his own decision is an ethical principle that has been interpreted into the legal concept of consent. Consent to medical treatment is a very fundamental aspect in medical law as it can be regarded as an acknowledgment that a patient has the right to make his own decision on what he wants to be done to his body. In the area of consent, capacity of the patient to make decision plays an important role. Capacity from the context of a patient's age is one of the factors that needs to be considered in deciding whether that particular patient has capacity to give consent or not. In this paper the focus will be on whether children governed by the Malaysian Child Act 2001 have the right to give consent to their medical treatment. In discussing this issue, the writers will look into the general legal position of children to give consent in Malaysia before going into the specific legal provisions pertaining to consent to medical treatment for children governed by the jurisdiction of the Child Act 2001. This is in order to give legal clarity to the issue of consent involving patients who are still children, primarily those taken under the protective wings of the Child Act 2001. For the purpose of this paper, the writers adopted the pure legalistic approach involving statute interpretation, reference to decided cases and comparative study to other relevant jurisdiction.

Keywords: capacity, child, consent, medical treatment.

\section{Introduction}

This paper aims to determine whether section 24 of the Child Act 2000 allows a child taken under the Act's jurisdiction to give his/her own consent to medical treatment. In order to do so, the writers will first refer to the existing Malaysian laws that are relevant to this issue to identify whether generally, a child patient in Malaysia can give a legally valid consent to his medical treatment. This issue needs to be addressed in order to give clarity and certainty to the law that can be used as a basis in medical and legal practice. At the end of this paper it will henceforth be determined whether there is a need to reform the laws pertaining to consent by a child patient in Malaysia.

\section{Definition of Child}

Most countries in this world have differing systems pertaining to adult and child patients. This is evident from the law applicable in each country. The International Convention on the Right of a Child defines "child" as:

Every human being below the age of eighteen years unless, under the law applicable to the child, majority is attained earlier."

In Malaysia, section 2 of the Child Act 2001 defines "child" as:

(a) A person who is under the age of 18 years and

(b) In relation to a criminal proceedings means, a person who has attained the age of criminal responsibility, as prescribed in section 82 of the Penal Code (Act 574) 
Section 2(1) The Guardianship of Infant Act 1961 defines "child" or "infant" as a person who has not attained his majority. Subsection 2(a)(i) further explains that for the purpose of this act, every person professing the religion of Islam shall be deemed to have attained his majority when he shall have completed his age of eighteen years and not before; and (ii)every other person shall be deemed to have attained his majority when he shall have completed his age of twenty one years and not before.

However, the categorization of age in the above Act is meant specifically for the implementation of the Act. Therefore for our present purpose, the term "child" in this paper refers to those who are under the age of 18 as defined in the Child Act 2001.

The term "child" is also synonym with the term "minor". Black's Law Dictionary (Gardner, 1999) defines "minor" as "someone who has not reached full legal age". Full legal age as has been mentioned before depends on the law of each particular country. There are countries which provide that 18 is the full legal age. On the other hand, country such as Singapore retains 21 years of age as the full legal age. Full legal age is crucial in determining whether a person has the legal capacity to manage his own affairs, for instance, in owning his own property, enter into business transactions or to get married without parental consent.(Dickens \& Cook, 2007)

This paper however, focuses on the legal capacity of a child patient to give his own consent to his medical treatment just like an adult patient who has full legal capacity and therefore entitled to make and give his own consent. The term child patient refers to a patient who has yet to attain full legal age in Malaysia, that is 18 years old.

Most issues relating to consent to medical treatment seldom arise in cases involving children who are too young as for this category of patients, their parents will play an important role in deciding whether to give consent or not to medical treatment (McHale, 2001). Therefore this paper will confine itself to cases involving patients on the verge of maturity.

It must be borne in mind that Malaysian is a Commonwealth country. Its legal system practices the common law system whereby legal principles from decided English cases are applicable to Malaysian cases only if there is a lacuna in the law and if it is not inconsistent with the local circumstances.(section 3 Civil Law Act 1956). Since there's no specific legal provision that gives a child patient the right to give his/her own consent to medical treatment, recourse can be made to cases decided by the English Court if issues of consent by a child below 18 years is being contested for being invalid in the Malaysian courts.

\section{Consent To Medical Treatment By Children: The Position Under the English Law}

Under the English Family Law Reform Act 1969 , rights are given to children who are 16 to 17 years old to give their own consent to medical treatment. By virtue of section 8(1) of the said Act, children who have reached 16 years of age have the legal capacity to give their consent without having to rely on the consent of their parents. Therefore, any contacts made during the giving of medical treatment will not expose the doctors to liabilities under the law of trespass. The consent given by the young patients are valid as if it was given by persons who are 18 years old and are considered as adults. Section 8 (1) Family Law Reform Act 1969 provides:

"The consent of a minor who has attained the age of sixteen years to any surgical, medical or dental treatment which, in the absent of consent, would constitute a trespass to his person, shall be as effective as it would be if he were of full age; and where a minor has by virtue of this section given an effective consent to any treatment it shall not be necessary to obtain any consent for it from his parent or guardian"

Nevertheless, this does not mean that consent by their parents will not be needed in all circumstances. In situations where children who are 16 to 17 years of age are found to be incompetent due to mental illness, the parents can give the needed consent to treatment on their behalf until the children reached the age of 18 years old(Brazier, 1992). Hence it can be seen that in England, consent by patients from 16 to 17 years of age are settled by virtue of section 8(1) Family Law Reform Act 1969.

However the issue remained at that time whether children below 16 years old have the legal capacity to give a valid consent to medical treatment. Doctors have always regarded 16 years as an age where patients are matured enough to give their own consent without having to rely on parental consent each and every time they need to receive medical treatment. Therefore, at the same time doctors tend to have the assumption that they are free to treat patients under 16 years old without getting parental consent beforehand if the patients are seen to be intelligent and matured enough to make their own decision. 
History showed that under the English common law, no specific age had been ascertained as an age where a child has the capacity to give consent (age of consent). It will depend on the factor of whether the child has the capacity to understand what is involved in the proposed procedure. Therefore, the assumption was that the law will accept the consent given by children who have the sufficient maturity to understand the proposed medical procedure or surgery (Skegg, 1973).

Based on the above assumption, it had been argued that section 8(3) of the Family Law Reform Act 1969 preserves the status quo for patients under the age of 16 years((1985) 3 All ER 402). The section provides:

"Nothing in this section shall be construed as making ineffective any consent which would have been effective if this section had not been enacted."

The assumption by doctors that they are free to treat patients under 16 years old without parental consent and that sub-section 3 of section 8 of the Family Law Act Reform 1969 became the main issues dealt with in the landmark case Gillick v West Norfolk and Wisbech Area Health Authority \& Anor.((1985) 3 All ER 402). This case finally dealt with the question of whether patients below 16 years old have the legal capacity to give a valid consent to medical treatment.

The House of Lords in this case decided that if a patient who is under the age of 16 years of age has shown that he or she has sufficient maturity to make his or her own decision, then that child can give a legally valid consent to any proposed medical procedure. Thus, he or she is said to be Gillick competent. Lord Scarman stated that :

"...I would hold as a matter of law that parental right to determine whether or not their minor child below the age of 16 will have medical treatment terminates if and when the child achieves a sufficient understanding and intelligence to enable him or her to understand fully what is proposed." ((1985) 3 All ER 423). His Lordship further stated: "...the parental right yields to the child's right to make his own decisions when he reaches a sufficient understanding and intelligence to be capable of making up his own mind on the matter requiring decision" ((1985) 3 All ER 422).

It had been held that the Gillick principle is not restricted to contraceptive cases only but it is also applicable to all cases relating to consent to medical treatment by children.

However this principle only applies to those below the age of 16 . This is because as has been discussed earlier, for patients who are 16 to 18 years of age section 8(1) of the English Family Reform Act 1969 is applicable.

There has not been a single decided case in Malaysia that deals with this issue. The common understand is that consent to medical treatment involving children below 18 years old must be given by the affected parents or guardian. (Puteri Nemie Jahn Kassim, 2007).

\section{The Existing Malaysian Laws}

In discussing the issue of the age of consent to medical treatment in Malaysia, reference will be made to several existing statutes namely, the Age of Majority Act 1971 the Child Act 2001, the Law Reform (Marriage and Divorce)Act 1976, and the Child Witness Act 2007.

\subsection{Age of Majority Act 1971}

In Malaysia, a person is said to be a child if he has not attained the age of majority as provided in Section 1 of the Age of Majority Act 1971. Section 2 of the same act provides:

"Subject to section 4, the minority of all males and females shall cease and determine within Malaysia at the age of eighteen years and every such male and female attaining that age shall be of the age majority."

Section 4 of the 1971 Act further provides:

"nothing in the Act shall effect:

(a)The capacity of any person to act in the following matters, namely marriage, divorce, dower and adoption;

(b) The religion and religious rites and usage of any class of persons within Malaysia;

(c)Any provision in any other written law contained fixing the age of majority for the purposes of that written law."

The exceptions in section 4 clearly do not refer to the capacity of children who have not yet attained the age of majority to give their own consent to medical treatment. Section 4(a) only refers to matters pertaining to marriage, 
divorce, dower and adoption. As there is no specific law giving rights to children to give consent to treatment, exception 3 is also irrelevant. Section 4(b) is obviously immaterial to this issue.

Based on this Age of Majority Act 1971 children below the age of 18 years are deemed to be incapable to give consent to medical treatment. The power to give consent lies on their parents as their legal guardian.

\subsection{The Child Act 2001}

As has been mentioned earlier, section 2 defines "child" as a person who is under the age of 18 years. This is in parallel with the Age of Majority Act 1971. According to Section 17 of the Child Act 2001 a child is considered to be in need of care and protection if he falls under any of the circumstances as stated by the provisions of the section. For example, a child will be deemed to be in need of care and protection if the child needs to be examined, investigated or treated for the purpose of restoring or preserving his health and his parent or guardian neglects or refuses to have him so examined, investigated or treated(Section 17 (f)(i)(ii) Child Act 2001).

Section 21 of this act further provides "a medical officer before whom a child is presented under:

(a) Shall conduct or cause to be conducted an examination of the child;

(b) May, in examining the child and if so authorized by a Protector or police officer, administer or cause to be administered such procedures and tests as , may be necessary to diagnose the child's condition; and

(c) May provide or cause to be provided such treatment as he considers necessary as a result of the diagnosis.

A protector is defined under section 2 as(a) the Director General, (b)the Deputy Director General, (c)a Divisional Director of Social Welfare, Department of Social v Welfare; (d)the State Director of Social Welfare of each of the States, (e)any Social Welfare Officer appointed under section 8.

If, in the opinion of a medical officer, the child referred to in section 21 requires treatment for a minor illness, injury or condition, a Protector or police officer may authorize such treatment.(Section 24(1)). Subsection 2 of the said section further states that if the child is suffering from a serious illness, injury or condition or requires surgery or psychiatric treatment, a Protector or police officer shall then notify or take reasonable steps to notify and consult the parent or guardian of the said child or any person having authority to consent to such treatment. In this circumstances, the Protector or police officer may also, with the written consent of the parent or guardian or such person, authorize such medical or surgical or psychiatric treatment as may be considered necessary by the medical officer(Section 24(2)).

Section 24 is a provision relating to authorization of medical treatment for a minor as defined in section 21. By virtue of section 24 , in any treatment for illness, injury or condition the authorization must first be obtained from a Protector or police officer.

It is important to note that this section gives a wide discretionary power to the Protector in making decision and henceforth authorising treatment to the child protected under this Act. This can be seen from subsection 3 of section 24 of the same Act where it provides that if a medical officer has certified in writing that there is immediate risk to the health of a child, a Protector may authorize, without obtaining consent referred to in subsection (2) above, such medical or surgical or psychiatric treatment as may be considered necessary by the medical officer. However, this power can only be used under any of the following circumstances:

a) that the parent or guardian of the child or any person having authority to consent to such treatment has unreasonably refused to give, or abstained from giving, consent to such treatment;

b) that the parent or guardian or the person referred to in paragraph (a) is not available or cannot be found within a reasonable time; or

c) the Protector believes on reasonable grounds that the parent or guardian or the person referred to in paragraph (a) has ill-treated, neglected, abandoned or exposed, or sexually abused, the child(Section 24(3)(a)-(c))

The Act unfortunately, neglected to define what is meant by "immediate risk to the health of a child". It also failed to define the phrase "unreasonably refused to give consent." (Section 24(3)(a)) and "within reasonable time"(section 24(3)(b)) as found in section 24(3) of the Act. Who will decide that the refusal of the parents or guardian to give consent is unreasonable? Also, what time frame is used to measure "reasonable time"? What is evident in this section is that the Protector has wide discretionary powers in the identified circumstances to give consent to any medical treatment, surgery or psychiatric treatment proposed by the medical officer to be given to the child who has been put under protection. It can be also concluded that those powers can override the rights of the parents to give or to refuse to give consent.

Sections 21 and 24 clearly do not arm the children put under the ambit of the Child Act 2001 with the rights to have a say in matters pertaining to their medical treatment.(Noor Aziah Awal, 2002). Any decision to be made is put under the jurisdiction of the Protector or the police officer involved. There is no indication in the stated provisions that the views and 
opinions of the children will be taken into consideration or given priority. The Child Act 2001 can be said to be a paternalistic act in matters concerning medical treatment of the children put under its wings. This can be said to have stemmed from the fact that the main aim of the Child Act 2001 is to protect and promote the welfare and interest of the children.

\subsection{Section 10 Law Reform (Marriage and Divorce) Act 1976.}

Section 10 of the Law Reform (Marriage and Divorce) Act 1976 provides:

Any marriage purported to be solemnized in Malaysia shall be void if at the date of the marriage either party is under the age of eighteen years, unless, for a female who has completed her sixteenth year, the solemnization of such marriage was authorized by a licence granted by the Chief Minister under subsection 21(2).

Section 21(2) states:

The Chief Minister may in his discretion grant a licence under this section authorizing the solemnization of a marriage although the female party to the marriage is under the age of eighteen years, but not in any case before her completion of sixteen years.

Therefore it is clear that the law permits a female person who is only 16 years of age and have not attained the age of majority to enter into a marriage contract which will bring with it a huge impact on her life. Even though licence given under section 21(2) is a condition, but that section does not state that a person has to prove that she is old and mature enough to take the final step.

Historically, section 10 was enacted as a result of a report made by the Royal Commission in virtue of the term of reference given to it by the Government of Malaysia. The Royal Commission was asked to determine whether there is a need for a law reform, by taking into consideration the resolution made by the United Nations relating to the minimum age for marriage( Official Report of the Malaysian Parliament, 1976). The three factors that had been taken into consideration in accordance to the Convention were:

1) Agreement to marry

2) Minimum age for marriage

3) Marriage registration

As a result of the term of reference, the Commission in its report recommended that the minimum age for marriage in Malaysia is to be 16 years old. The recommendation was eventually enacted as law in the Law Reform. (Marriage and Divorce) Act 1976 as mentioned above. Thus it can be concluded that in this instance, the law regards a female person of 16 years as competent to enter into a marriage contract.

\subsection{Evidence of Child Witness Act 2007}

Section 13 of the Evidence of Child Witness Act 2007 provides:

When a child witness is giving evidence before the Court and in the course of giving evidence he attains the age of sixteen years, the Court shall continue to hear the evidence of that child witness and exercise all the powers under the Act.

The above provision can be deemed to mean that as a basis, a witness who is of sixteen years and above, can give evidence as an adult. This basis is further explained by section 2 of the same Act which interpreted a child witness as someone is is below sixteen years old. Section 2 of the Child Witness Act 2007 states: child witness means a person under the age of sixteen years who is called or proposed to be called to give evidence in any proceedings but does not include an accused or a child charged with any offence.

It can therefore be argued that the implication from both sections is that, for the purpose of giving admissible evidence in court, there are laws in Malaysia that have already acknowledged that a child who has attained 16 years of age has the necessary intellectual capacity as if he is already 18 years old and above. 


\section{The Malaysian Scenario: Points to Ponder.}

The main issue that needs to be addressed is whether a child patient who is found to be competent and has the capacity to make his or her own decision should be given the rights to give his or her own consent to medical treatment. This is because as has been stated above, consent to medical treatment is not included in the exceptions under section 4 of the Age of Majority Act 1971.

Hence, should the issue of consent by a child patient be eventually brought to court, the writers opined that there are several points that must be considered by the courts and they are:

a. The court might want to consider applying the Gillick principle if the court is of the opinion that that principle is applicable in Malaysia notwithstanding the existence of section 4 of Age of Majority Act 1971 and section 2 of the Child Act 2001. However if the court chooses to give a strict interpretation to those two provisions, and decided that the provisions do not allow any exceptions be made regarding consent to treatment by children who have not attained the age of majority, then the common law principle as enunciated in the Gillick case can never be applied in Malaysia.

b. Alternatively, should the Malaysian court decided to follow the Gillick principle by not interpreting section 4 of the Age of Majority Act 1971 and section 2 of the Child Act 2001 strictly, then the next question to be asked is whether the Gillick principle will be applicable to all children below 18 years old or it can only be applied to those below 16 years old. This is because taking into account that the Gillick principle was aimed at children below the age of 16 years as in England there is already in existence section 8(1) of Family Law Reform Act 1969 that caters to patients between 16 to 17 years of age. As English statutes cannot be applied in Malaysia, this will render patients between the age bracket of 16 years old but have not reached 18, be left without any specific legal provision that allows them to give their own consent to treatment.

c. Another point that needs to be looked into is that should the courts in Malaysia chose to apply the Gillick principle to cases involving the issue of consent to medical treatment by children, the court must also take into account that as a common law principle cannot be applied where there is already in existence a specific legal provision pertaining to the matter, it is therefore clear that the Gillick principle relating to consent by a minor, is not applicable for those patients governed by Section 24 of the Child Act 2001. Therefore, if it was decided by the Malaysian courts that children below 16 years old can give consent to treatment, this will undoubtedly cause a discrepancy between the rights given to children not governed by the Child Act 2001 and those who are so governed in respect of consent to medical treatment.

\section{Conclusion}

From the discussion in this paper, it is clear that there is a legal uncertainty and ambiguity regarding the age of consent to medical treatment. Therefore, it is humbly suggested that there be promulgated a specific statute to give rights to patients who are not yet 18 to give their own consent to medical treatment. A specific age bracket must be determined in which a child patient is allowed to give his/her own consent to treatment. Children of that specified age bracket must be presumed competent unless found to be the opposite by a psychiatric. Further, this right must of course come with a proviso. For example consent can only be given by a child patient if it does not involve a life or death situation or an irreversible procedure such as organ transplantation. In such situation parental consent should and will be, resorted to.

\section{References}

Brazier, M.(1992). Medicine, Patients and the Law. London: Penguin Books.

Dickens, B.M \& Cook, R.J.(2000). Adolescents and Consent to Treatment, Ethical and Legal Issues in Reproductive Health, International Journal of Gynaecology \& Obstetrics.

Gardner, B.A.(ed)(1999). Black's Law Dictionary 7thedition. St. Paul, Minnesota: West Group.

McHale, (2001). Health Care Law: Text, Cases and Materials, London: Sweet\&Maxwell.

Noor Aziah Awal Mohd.Awal (2002). Child Act 2001, How Far Does It Conform To The UNCRC?. In Siti Zaharah Jamaluddin, et.al.,(ed), SiriUndang-undang Mimi Kamariah, Akta Kanak-kanak 2001. Kuala Lumpur: Penerbit Universiti Malaya.

Puteri Nemie Jahn Kassim.(2007). Law and Ethics Relating to Medical Profession. Petaling Jaya: International Law Books Services.

Skegg, P.D.G. (1984). Law, Ethics and Medicine, Oxford: Clarendon Press.

Skegg, P.D.G.(1973). Consent to Medical Procedures on Minors. The Modern Law Review, 370. 